\title{
ЕФЕКТИВНІСТЬ ЗАСТОСУВАННЯ СПОСОБУ ВТОРИННОЇ ПРОФІЛАКТИКИ ФЛЮОРОЗУ ПОСТІЙНИХ ЗУБІВ У ДІТЕЙ
}

Кафедра дитячої терапевтичної стоматології з профілактикою стоматологічних захворювань (зав. - проф. Л. Ф. Каськова)

ВДНЗУ «Українська медична стоматологічна академія»<stomat@umsa.edu.ua>

3 метою вивчення ефективності застосування кальиійорганічного препарату кальцекс проведено дослідження 80 учнів середніх загальноосвітніх шкіл з проявами початкових форм флюорозу на зубах. Результати клінічних досліджень показали, що запропонований спосіб вторинної профілактики флюорозу запобігає розвитку забарвлення $і$ деструкцї уражених ділянок емалі та сприяє усуненню крейдоподібних флюорозних плям, що підтверджується підвищенням омічного опору твердих тканин постійних зубів у дітей.

Ключові слова: діти, флюороз, постійні зуби, вторинна профілактика.

Вступ. Вивчення стоматологічного здоров’я дитячого населення показало збільшення поширення та інтенсивності основних стоматологічних захворювань під впливом різноманітних чинників та розвитку цивілізації $[4,5]$. При цьому визначна роль у виникненні різних груп уражень твердих тканин зубів належить місцевим біогеохімічним та екологічним факторам, особливо фтору, який є визнаним протикаріозним засобом. Проте вживання питної води та продуктів харчування з підвищеним і високим вмістом фтору, а також надмірне надходження цього галогену та його сполук з атмосферним повітрям тривалий час призводить до перенасичення організму фтором, зовнішнім проявом якого є флюороз зубів [2].

Значне поширення флюорозу на території України не лише в регіонах з підвищеним вмістом фтору в питній воді, але і в місцевостях з оптимальною і навіть зниженою концентрацією цього мікроелемента у водних джерелах обумовлює актуальність даного захворювання [2, 3].

Різні засоби та методи первинної профілактики флюорозу не завжди запобігають розвитку цього захворювання. Крім того, вони нерідко потребують великих матеріальних витрат, що є перешкодою до їх здійснення, особливо у сільській місцевості, отже, існує необхідність вторинної профілактики фтористої інтоксикації.

Для вторинної профілактики флюорозу зубів запропоновано декілька методик [7], але авторами не простежена їх ефективність, відсутні рекомендації з кратності курсів лікування та можливість вибору способу введення препарату до твердих тканин зубів. Тому пошук нових, ефективних засобів для вторинної профілактики флюорозу постійних зубів - актуальне завдання практичної стоматології.

Мета дослідження - розробка нового, ефективного, доступного і науково обгрунтованого способу вторинної профілактики флюорозу постійних зубів у дітей.

Матеріали і методи. Під час теоретичного пошуку надійних та ефективних засобів для вторинної профілактики флюорозу, які б дозволили за порівняно нетривалий час надати емалі природного вигляду, нашу увагу привернув препарат кальцекс, до складу якого входять комплексна сіль гексаметилентетраміну та кальцій хлориду. Кальцекс характеризується легкою засвоюваністю, легкою розчинністю у воді, він високоефективне джерело кальцію, відсотковий вміст якого становить 13,5. Його рекомендують для використання у різних галузях медицини. Для екзогенної вторинної профілактики флюорозу раніше не застосовували.

3 метою вивчення ефективності застосування кальційорганічного препарату кальцекс проведено дослідження 80 учнів 1-3 класів середніх загальноосвітніх шкіл з проявами початкових форм флюорозу на зубах, які належали до I та II груп 
здоров’я і проживали у Полтаві в однакових соціально-побутових умовах. Вибір такої вікової групи був обумовлений термінами прорізування зубів та твердженням про те, що кінцеве дозрівання емалі особливо інтенсивно відбувається протягом першого року після прорізування зуба [6]. Тобто ми припустили, що запропоновані нами лікувально-профілактичні заходи в цей період, імовірно, будуть мати найвищий ефект.

Дітей обстежено на базі Полтавської міської дитячої клінічної стоматологічної поліклініки, воно включало опитування, клінічну оцінку стану органів порожнини рота та фізичні методи дослідження.

Під час збору скарг і анамнезу з'ясовували місце народження, місце й умови проживання дитини, джерело водопостачання, характер вигодовування, перенесені та супутні захворювання, відвідування дошкільних закладів. Особливу увагу приділяли оздоровчим заходам (сезонні виїзди влітку на відпочинок) та анамнезу щодо профілактики флюорозу зубів.

Оцінку проявів флюорозу зубів проводили згідно з критеріями Dean, як рекомендовано експертами ВООЗ [8]. Реєстрацію флюорозу від 0 до 5 проводили на підставі оцінки за критеріями (балами) Dean двох найбільш уражених зубів. При цьому початковими вважали дуже легкі форми флюорозу, при яких крейдяні зміни емалі становили менше 25 \% зубної поверхні - 2 бали та легкі з ураженням від 25 \% до 50 \% поверхні зуба - 3 бали.

Визначення площі крейдяних плям проводили запропонованим нами способом [1].

Критерієм поліпшення стану ураженої емалі вважали зникнення або зменшення розмірів крейдяних плям. Критерієм погіршення стану вважали збільшення розмірів ураженої флюорозом емалі, виникнення нових крейдяних плям, пігментації або ерозії. При стабілізації процесу розмір флюорозних плям, їх колір та цілісність емалі не змінювались.

Показник омічного опору твердих тканин зубів визначали за методикою А. К. Ніколішина з використанням пристрою для електродіагностики карієсу УДК - 87 [7]. Нормою, згідно з нашими результатами та даними автора, вважали такі значення опору: для центральних різців - від 121 до 142 МОм, для латеральних різців - від 100 до 111 МОм.

Залежно від концентрації препарату (5 і 10 \%), способу його застосування (аплікація, фоно- і електрофорез) та кількості сеансів на курс терапії (5 і 10 - для аплікацій і електрофорезу та 4 і 8 - для фонофорезу) школярів розподілено на дванадцять груп. Діти у групах були порівнянні за віком, статтю і вираженістю проявів флюорозу зубів.

При застосуванні аплікацій ватний тампон, зволожений розчином, на 5 хв накладали на зуби, попередньо очищені від нальоту та ізольовані від слизової оболонки. Тампони міняли тричі підряд. Термін загальної експозиції розчину становив 15 хв. У домашніх умовах аплікації рекомендували проводити на ніч.

Електро- і фонофорез препарату проводили в поліклінічних умовах на відповідному обладнанні. Після кожної процедури рекомендували утриматися від вживання їі протягом 2 год.

Ефективність терапії оцінювали за динамікою змін клінічних показників у період лікування та через 3; 6 міс і 1 рік після закінчення курсу лікувальнопрофілактичних заходів.

Отримані дані обробляли методом варіаційної статистики. Оцінку достовірності різниці показників проводили методом різниць. Відмінності вважали достовірними при $\mathrm{P} \leq 0,05$.

Результати та ї обговорення. Аналіз клінічних результатів показав, що застосування запропонованого лікувально-профілактичного комплексу сприятливо впливає на перебіг флюорозу зубів.

Через рік після проведеного курсу лікування (екзогенна вторинна профілактика) погіршення стану ураженої флюорозом емалі не зареєстровано в жодному зубі. Стабілізацію виявлено в $(56,23 \pm 2,96)$ \% зубів. У цій групі превалював дуже 
легкий флюороз (35,59 \% $\pm 2,86 \%$ зуба), але були й зуби з легкою формою $(20,64 \% \pm 2,41$ \% зуба). Поліпшення стану ураженої флюорозом емалі діагностували у $(43,77 \pm 2,96) \%$ зубів. 3 них у $(28,47 \pm 2,69) \%$ спочатку був дуже легкий флюороз, а в $(15,30 \pm 2,15) \%$ - легкий. Поліпшення проявлялося не лише у зменшенні розмірів флюорозних плям у $(37,37 \pm 2,89) \%$ зубів, а й у повному їх зникненні у $(6,40 \pm 1,46) \%$ зубів.

Клінічна ефективність проведених лікувально-профілактичних заходів підтверджувалась позитивною динамікою омічного опору в період лікування та через 3 і 6 міс після закінчення курсу профілактики.

Відразу після застосування для місцевого лікування флюорозу у дітей аплікацій кальційорганічного препарату кальцекс омічний опір твердих тканин зубів достовірно збільшувався в 1,04 раза $(\mathrm{P}<0,01)$ при використанні 5 сеансів $5 \%$ розчину препарату, в 1,08 раза $(\mathrm{P}<0,01)-10$ сеансів $5 \%$ розчину, в 1,18 раза $(\mathrm{P}<0,001)-5$ сеансів $10 \%$ розчину та в 1,33 раза $(\mathrm{P}<0,001)-10$ сеансів $10 \%$ розчину препарату.

Призначення електрофорезу кальцексу відразу після курсу лікування супроводжувалося достовірним збільшенням опору в 1,24 раза $(\mathrm{P}<0,01)$ за 5 сеансів $5 \%$ розчину кальційорганічного комплексу, в 1,25 раза $(\mathrm{P}<0,001)-10$ сеансів $5 \%$ концентрації, в 1,3 раза $(\mathrm{P}<0,01)-5$ сеансів $10 \%$ розчину та в 1,33 раза $(\mathrm{P}<0,001)-10$ сеансів $10 \%$ розчину препарату.

Використання для місцевого лікування флюорозу фонофорезу кальційорганічного комплексу відразу після курсу терапії приводило до достовірного збільшення омічного опору в 1,15 раза $(\mathrm{P}<0,001)$ після 5 сеансів $5 \%$ розчину кальцексу, в 1,15 раза $(\mathrm{P}<0,01)-10$ сеансів $5 \%$ розчину, у 1,24 раза $(\mathrm{P}<0,001)-$ 5 сеансів $10 \%$ концентрації та в 1,33 раза $(\mathrm{P}<0,001)$ - 10 сеансів $10 \%$ розчину препарату.

Отже, відразу після курсу лікувально-профілактичних заходів при флюорозі постійних зубів у всіх клінічних групах значення омічного опору достовірно збільшувалось. Однак порівняння груп між собою у межах одного способу застосування показало, що збільшення удвічі лише концентрації препарату або тільки кількості сеансів лікування не мало достовірної різниці $(\mathrm{P}>0,05)$, хоча і супроводжувалося тенденцією до підвищення приросту опору. Одночасне підвищення і кількості процедур, і концентрації препарату дозволило досягти достовірного збільшення значень приросту омічного опору твердих тканин зубів у понад 4 рази при застосуванні аплікацій $(\mathrm{P}<0,001)$ та майже вдвічі - при застосуванні фонофорезу $(\mathrm{P}<0,02)$. У групах, в яких використовували для лікування електрофорез кальційорганічного комплексу, одночасне підвищення вищевказаних параметрів не мало достовірної різниці (P > 0,05), хоча при застосування 10 сеансів електрофорезу 10\% розчину кальцексу приріст омічного опору був майже удвічі більшим, ніж у разі призначення 5 сеансів 5\% розчину цього препарату.

При порівнянні результатів лікування (екзогенна вторинна профілактика) флюорозу кальційорганічним комплексом при різних способах його застосування встановлено, що використання електро- чи фонофорезу кальцексу майже вдвічі ефективніше, ніж призначення аплікацій. При цьому порівняння ефективності лікування електро- і фонофорезом не мало суттєвої різниці $(\mathrm{P}>0,05)$.

За результатами обстеження дітей через 3 міс підтвердилась висока ефективність проведеного курсу терапії. У хворих відмічали достовірно більш виражений приріст значень омічного опору, ніж відразу після лікування ( $<<0,01$ і $\mathrm{P}<0,001)$. При цьому приріст його збільшувався при підвищенні концентрації препарату та кількості сеансів на курс лікування. Порівнюючи значення опору до лікування та через 3 міс після завершення курсу терапії, ми встановили, що у $(95,73 \pm 1,21) \%$ зубів відбулося збільшення омічного опору, а у $(38,08 \pm 2,90)$ \% з них значення його досягли норми.

Слід зазначити, що через півроку після курсу лікувально-профілактичних заходів порівняно з результатами через 3 міс приросту значень омічного опору не 
відбувалося, але поряд з цим досліджуваний показник не знижувався до вихідних значень.

На нашу думку, такі результати отримані завдяки вмісту у препараті кальцекс органічної речовини, водний розчин якої має лужну реакцію (рH 40 \% розчину 7,8-8,2), що збільшує проникність іонів кальцію у тканини зуба і підвищує омічний опір.

Висновки. Таким чином, запропонований спосіб вторинної профілактики флюорозу зубів запобігає розвитку забарвлення і деструкції уражених ділянок емалі та сприяє усуненню крейдоподібних флюорозних плям, що підтверджується підвищенням омічного опору твердих тканин і не потребує у подальшому використання інших лікувальних заходів, які можуть бути небезпечними для твердих тканин зубів дітей. Висока ефективність запропонованого способу вторинної профілактики флюорозу зубів з використанням кальційорганічного препарату кальцекс підтверджує можливість його застосування для лікування флюорозу постійних зубів у вигляді крейдоподібних плям. Спосіб простий у виконанні, доступний, дешевий і тому може бути рекомендований до застосування у практичній стоматології.

$$
\text { С пи сок л і те ра т у ри }
$$

1. Амосова Л. I., Старіщина Н. Г. Спосіб визначення площі флюорозних і каріозних плям емалі та їх динаміки // Сучасні підходи до лікування та профілактики основних стоматологічних захворювань: Матеріали Всеукр. наук.-практ. конф. Івано-Франківськ, 2003. - С. 35-36.

2. Безвушко $C$. В. Забруднене довкілля як фактор ризику виникнення флюорозу зубів у дітей // Новини стоматології. 1999. - № 3. - С. 41-42.

3. Каськова Л. Ф., Падалка І. О., Амосова Л. I. та ін. Обгрунтування диференційованого підходу до вторинної профілактики флюорозу постійних зубів у дітей // Профілакт. та дитяча стоматологія. - 2011. № 1. - C. 37-41.

4. Каськова Л. Ф., Артемьев А. В., Бережная Е. Э., Амосова Л. И. Особенности стоматологического статуса населения территории Украины в разные исторические эпохи // Мед. новости Грузии. - 2014. Вып. 237, № 12. - С. 35-40.

5. Каськова Л. Ф., Марченко К. В., Бережна О. Е., Амосова Л. I. Динаміка показників карієсу у дітей із зубощелепними аномаліями під впливом профілактичних заходів // Лік. справа=Врачеб. дело. - 2015. № $1-2$. - C. $63-67$.

6. Марченко А. В., Іленко Н. М., Ніколішинa E. B. Патоморфологічні підходи щодо лікування флюорозу зубів // Укр. стоматол. альманах. - 2000. - № 1. - С. 5-6.

7. Николишин А. К. Флюороз зубов. Клиника, диагностика, лечение и профилактика. Ч. ІІ. - Полтава: Полтава, 1995. - 74 с.

8. Стоматологические обследования: основные методы: Пер. с англ. А. Г. Колесника. [3-е изд.]. - Женева: ВОЗ, 1989. - 62 с.
1. Amosova L. I., Staricina N. G. Sposib viznachennya ploshchi flyuoroznih i karioznih plyam emali ta ïh dinamiki // Suchasni pidhodi do likuvannya ta profilaktiki osnovnih stomatologichnih zahvoryuvan': Materiali Vseukr. nauk.-prakt. konf. - IvanoFrankivs'k, 2003. - S. 35-36.

2. Bezoushko $C$. V. Zabrudnene dovkillya yak faktor riziku viniknennya flyuorozu zubiv u ditej // Novini stomatologiï. - 1999. № 3. - S. 41-42.

3. Kas'kova L. F., Padalka I. O., Amosova L. I. ta in. Obrruntuvannya diferencijovanogo pidhodu do vtorinnoï profilaktiki flyuorozu postijnih zubiv u ditej // Profilakt. ta dityacha stomatologiya. - 2011. - № 1. - S. 3741.

4. Kas'kova L. F., Artem'ev A. V., Berezhnaya E. Eh., Amosova L. I. Osobennosti stomatologicheskogo statusa naseleniya territorii Ukrainy v raznye istoricheskie ehpohi // Med. novosti Gruzii. - 2014. Vyp. 237, № 12. - S. 35-40.

5. Kas'kova L. F., Marchenko K. V., Berezhna O. E., Amosova L. I. Dinamika pokaznikiv kariesu u ditej iz zuboshchelepnimi anomaliyami pid vplivom profilaktichnih zahodiv // Lik. sprava=Vracheb. delo. -2015 . № 1-2. - S. 63-67.

6. Marchenko A. V., Ilenko N. M., Nikolishina E. $V$. Patomorfologichni pidhodi shchodo likuvannya flyuorozu zubiv // Ukr. stomatol. al'manah. - 2000. - № 1. - S. 5-6.

7. Nikolishin A. K. Flyuoroz zubov. Klinika, diagnostika, lechenie i profilaktika. Ch. II. Poltava: Poltava, 1995. - 74 s.

8. Stomatologicheskie obsledovaniya: osnovnye metody: Per. s angl. A. G. Kolesnika. - [3-e izd.]. - Zheneva: VOZ, 1989. - 62 s. 
ЭФФЕКТИВНОСТЬ ПРИМЕНЕНИЯ СПОСОБА ВТОРИЧНОЙ ПРОФИЛАКТИКИ ФЛЮОРОЗА ПОСТОЯННЫХ ЗУБОВ У ДЕТЕЙ

\section{Л. Ф. Каськова, Л. И. Амосова, Е. Э. Бережная, Ю. И. Солошенко, Н. А. Моргун (Полтава)}

С целью изучения эффективности применения кальцийорганического прапарата кальцекс обследовано 80 учеников средних общеобразовательных школ с проявлениями начальных форм флюороза на зубах. Результаты клинических исследований показали, что предложенный способ вторичной профилактики флюороза предупреждает развитие окрашивания и деструкции поражённых участков эмали и способствует устранению меловых флюорозных пятен, что подтверждается повышением омического сопротивления твёрдых тканей постоянных зубов у детей.

Ключевые слова: дети, флюороз, постоянные зубы, вторичная профилактика.

\section{EFFECTIVENESS OF WAY OF SECONDARY PREVENTION OF FLUOROSIS OF THE PERMANENT TEETH IN CHILDREN}

\section{F. Kaskova, L. I Amosova, O. E. Berezhnaya, Y. I. Soloshenko, N. A. Morgun (Poltava, Ukraine) \\ Ukrainian medical stomatological academy}

In order to study the efficacy of calcium-organic complex calcex surveyed 80 students of secondary schools with displays of early forms of fluorosis on the teeth. Clinical studies have shown that the proposed method of secondary prophylaxis prevents the development of dental fluorosis staining and degradation of enamel lesions and helps eliminate flyuorosis' chalky spots, as evidenced by an increase in the ohmic resistance of hard tissues of permanent teeth in children.

Key words: children, fluorosis, permanent teeth, secondary prevention.

\section{ЕКСПЕРИМЕНТАЛЬНІ ДОСЛІДЖЕННЯ}

\section{КІЛЬКІСНА ХАРАКТЕРИСТИКА СТРУКТУРНИХ ЗМІН В ЯСЧКАХ ЩУРІВ В УМОВАХ ПОСТСТРУМЕКТОМІЧНОГО ГІПОТИРЕОЗУ}

Кафедра анатомії людини (зав. - проф. І. Є. Герасимюк) ДВНЗ «Тернопільський державний медичний університет ім. І. Я. Горбачевського МОЗ України»<oks.illkiv@gmail.com>

Проблема чоловічого безпліддя була і залишається актуальним питанням сучасної медичної науки. Однією з причин виникнення безпліддя є, безумовно, гормональні дисбаланси, які закономірно виникають, зокрема, після струмектомії. Разом з тим морфогенетичні механізми порушення сперматогенної функцї при гіпотиреозі вивчені недостатньо. Тому важливим є дослідження динаміки структурних змін у яєчках шурів при постструмектомічному гіпотиреозі та їх об'єктивна кількісна характеристика, що дозволить глибще розкрити патогенез чоловічого безпліддя і тим самим покрашити діагностику та медикаментозну корекиію. Експерименти проведено на статевозрілих білих лабораторних щурах-самиях, яким під кетаміновим знеболенням проводили струмектомію. Застосування органометрії, дослідження гістологічних зрізів яєчок з їх морфометричною характеристикою і статистичною обробкою цифрового матеріалу дозволило встановити, що у статевих залозах щурів-самців після струмектомії виникають значні дистрофічні зміни в стромі і паренхімі органу, які розвиваються на фоні 